\title{
Kajian Perbandingan Analisis Pasang Surut dengan Menggunakan Metode Least Square dan Fourier di Perairan Barat Sumatera
}

\author{
Hanifa Zuhaira $^{1 *}$, Gentur Handoyo ${ }^{1}$, Purwanto ${ }^{1}$, Agus Anugroho Dwi Suryo P $^{1}$, dan Sri Yulina ${ }^{1}$ \\ ${ }^{I}$ Departemen Oseanografi, Fakultas Perikanan dan Ilmu Kelautan, Universitas Diponegoro \\ Jl. Prof. H. Sudarto, SH, Tembalang Telp. I fax (024) 7474698 Semarang 50275 \\ *Email: hanifazuhaira@student.undip.ac.id
}

\begin{abstract}
Abstrak
Indonesia memiliki wilayah yang sebagian besar adalah perairan. Posisinya yang strategis, Indonesia menjadi salah satu yang memiliki potensi untuk berbagai aktivitas kelautan. Umumnya dalam mendukung aktivitas kelautan perlu diketahui gerakan naik turunnya permukaan laut yaitu pasang surut (Supriyono et al., 2015). Ketersediaan data pasang surut yang akurat dan kontinu masih sangat terbatas. Besar usaha dan biaya yang dibutuhkan menjadi permasalahan dalam pengambilan data pasang surut. Ahli oseanografi akhirnya banyak memanfaatkan model prediksi pasang surut (Syahputra dan Nugraha, 2017). Model-model tersebut memberikan hasil analisis yang berbeda-beda karena seiring berkembangnya zaman dan semakin meningkatnya teknologi komputer, sehingga model pasang surut tersebut banyak dikembangkan. Banyaknya ahli yang mengembangkan model pasang surut tersebut dapat memberikan hasil analisis dan resolusi yang berbeda-beda dengan hasil yang lebih akurat. Tujuan dari penelitian ini yaitu untuk mengkaji perbandingan analisis pasang surut antara metode Least Square dan Fourier di Perairan Barat Sumatera, dan mengetahui karakteristik pasang surutnya. Penelitian ini menggunakan data 3 lokasi stasiun pasang surut, yaitu Meulaboh, Sibolga dan Padang selama 5 tahun dari tahun 2014 hingga 2018. Berdasarkan penelitian yang dilakukan, analisis kedua model memberikan perbedaan dan persamaan pada beberapa parameter. Perbedaan yang diperoleh berada pada jumlah komponen yang dihasilkan yaitu metode Least Square mengidentifikasi komponen yang lebih banyak sebanyak 68 komponen. Persamaan dari kedua metode yaitu diperoleh tipe pasang surut Campuran Condong Harian Ganda dengan nilai Formzahl rata-rata sebesar 0,36, dan pembentukan pasang surut didominasi komponen M2 dengan nilai amplitude rata-rata sebesar 0,258 meter.
\end{abstract}

Kata Kunci : Least Square, Fourier, Pasang Surut, Perairan Barat Sumatera

\begin{abstract}
Indonesia has a territory largely is sea. Its strategic position, Indonesia is one that has the potential for various marine activities. Generally in supporting marine activities it is necessary to know the movement of sea-level rise, is tides (Supriyono et al., 2015). The availability of accurate and continuous tidal data is still very limited. The amount of effort and cost required is one of problem in collecting tidal data. Many oceanographers utilize of tidal prediction models (Syahputra and Nugraha, 2017). These models provide different analysis results because the increasing of computer technology so that the tidal models are widely developed. Many experts who developed the tidal model can provide different analysis and resolution results with more accurate results. The purpose of this study to examine the comparison analysis Least Square and Fourier methods in West Sumatra, and determine the tidal characteristics. This study used 3 tidal stations, Meulaboh, Sibolga, and Padang for 5 years from 2014 to 2018. Based on the analysis done, obtained of tidal models with both methods provided differences and similarities in several parameters. The difference obtained in the number of components produced, the Least Square method identified more components. The similarity of the two methods were obtained tidal characteristics in the West Sumatera that were Mixed Tide Prevailing Semi Diurnal with an average Formzahl value were 0.36, and dominated by the M2 component with an average amplitude value were 0.258 meters.
\end{abstract}

Keywords : Least Square, Fourier, Tides, West Sumatra

\section{PENDAHULUAN}

Negara kepulauan Indonesia memiliki wilayah dengan sebagian besar yaitu perairan. Posisinya yang strategis Indonesia menjadi salah satu yang memiliki potensi untuk berbagai aktivitas kelautan. Umumnya dalam mendukung kegiatan kelautan seperti aktivitas transportasi dalam perairan, perlu 
diketahui gerakan naik turunnya permukaan laut yaitu pasang surut (Supriyono et al, 2015). Menurut Pariwono (1989), pasang surut dapat dikaitkan dengan gerakan naik turunnya permukaan laut atau paras laut, yang diakibatkan oleh gerakan gaya tarik benda-benda astronomi secara berkala. Khususnya oleh matahari dan bulan terhadap massa air di bumi.

Ketersediaan data pasang surut yang akurat dan kontinu masih sangat terbatas. Sulitnya melakukan pengambilan data pasang surut serta besar usaha dan biaya yang dibutuhkan masih menjadi permasalahan. Para ahli oseanografi akhirnya memanfaatkan model-model prediksi pasang surut, yang mana masih memiliki tingkat akurasinya yang berbeda. Model-model tersebut sangat penting guna mempresentasikan kondisi perairan apakah sudah mendekati sebenarnya atau tidak (Syahputra dan Nugraha, 2017). Model prediksi pasang surut dengan menggunakan program aplikasi, salah satunya bertujuan untuk menguraikan komponen harmonik pasang surut. Komponen harmonik pasang surut dapat diperoleh setelah melakukan analisis harmonik, dimana komponen tersebut berguna dalam mengetahui informasi mengenai karakteristik dan tipe pasang surut (Richasari et al., 2019). Modelmodel tersebut memberikan hasil analisis yang berbeda-beda karena seiring berkembangnya zaman dan semakin meningkatnya teknologi komputer, maka model pasang surut tersebut banyak dikembangkan. Banyaknya ahli yang mengembangkan model pasang surut tersebut dapat memberikan hasil analisis dan resolusi yang berbeda-beda dengan hasil yang lebih akurat.

Meninjau pentingnya model pasang surut untuk digunakan sebagai perencanaan, pembangunan serta pengembangan wilayah, maka penelitian ini penting dilakukan. Perlu untuk melihat hasil model pasang surut dengan menggunakan metode Least Square dan Fourier dengan menggunakan data yang panjang guna diharapkan memperoleh model prediksi yang mendekati sebenarnya.

\section{MATERI DAN METODE}

\section{Materi Penelitian}

Materi yang digunakan dalam penelitian ini yaitu menggunakan data primer. Data primer yang digunakan merupakan data observasi pasang surut real-time yang digunakan untuk pengolahan data. Data tersebut diperoleh dari Badan Informasi Geospasial (BIG), berupa data pasang surut pada Perairan Barat Sumatera di 3 titik pengamatan, yaitu stasiun Meulaboh, Sibolga dan Padang. Data observasi tersebut selama 5 tahun (2014-2018) dengan interval waktu 1 jam.

\section{Metode Penelitian}

Metode yang digunakan dalam penelitian ini yaitu metode kuantitatif. Menurut Sugiyono (2009), metode kuantitatif dapat diartikan sebagai metode yang menggunakan data berupa angka-angka dari pengumpulan data. Penampilan dari hasilnya dapat berupa gambar, tabel, grafik atau tampilan lainnya. Metode penelitian kuantitatif diartikan juga sebagai metode penelitian untuk menguji teori, membangun fakta, kemudian ditunjukkan hubungan antar variabelnya dan memberikan deskripsi statistik serta meramalkan hasil. Data di dalam penelitian ini merupakan data yang diproses dengan menggunakan 2 metode yaitu metode Least Square dan Fourier yang memberikan hasil model yang bersifat sistematis.

\section{Metode Pengolahan Data Pasang Surut Metode Least Square}

Pengolahan data pasang surut pada penelitian ini menggunakan metode Least Square dan Fourier. Metode Least Square yang digunakan pada penelitian ini yaitu dengan menggunakan perangkat t_tide yang dijalankan dengan Matlab 2015a untuk mendapatkan prediksi dan nilai komponen pasang surut. Hasil pada Least Square menampilkan grafik perbandingan prediksi dan data lapangan serta komponen dengan besar nilai amplitudo dan fase.

\section{Metode Fourier}

Pada Fourier dengan metode Fast Fourier Transform diolah dengan Matlab 2015 a juga untuk mendapatkan hasil transformasi pasang surut menjadi domain frekuensi yang mempunyai amplitudo 
tertentu. Hasil Fourier menampilkan grafik sinyal frekuensi dan nilai amplitudo komponen pasang surut.

\section{HASIL DAN PEMBAHASAN}

\section{Metode Least Square}

Pengamatan pasang surut yang dilakukan pada penelitian ini yaitu berada di 3 titik bagian Perairan Barat Sumatra. Rentan waktu penelitian ini yaitu selama 5 tahun. Selama pengamatan pasang surut diperoleh datum pasang surut yang disajikan pada Tabel 1.

Tabel 1. Datum Pasang Surut di 3 lokasi Perairan Barat Sumatera

\begin{tabular}{cccc}
\hline Stasiun & HWL (m) & MSL (m) & LWL (m) \\
\hline Meulaboh & 2,19 & 1,56 & 0,95 \\
Sibolga & 2,99 & 2,01 & 1,31 \\
Padang & 4,23 & 3,16 & 2,31 \\
\hline
\end{tabular}

Proses pengolahan data pasang surut dilakukan pada metode Least Square ini yaitu dengan menggunakan perangkat $t$ tide. Pengolahan data tersebut menghasilkan hasil model prediksi pasang surut. Prediksi tersebut selanjtunya dapat dibandingan dengan data observasi pasang surut. Perbandingan disajikan dalam bentuk grafik pada Gambar 1.

Disamping memperoleh grafik perbandingan pasang surut observasi dan prediksi, $t$ _tide juga mengidentifikasi konstituen pasang surut. Masing-masing stasiun mengidentifikasi 68 konstituen pasang surut yang terdiri dari komponen astronomis dan komponen perairan dangkal. Pembagian komponen tersebut berdasar dari pengaruh pasang surutnya. Hasil keseluruhan komponen yang diperoleh juga mengidentifikasi komponen yang mendominasi di Perairan Barat Sumatera. Komponen dominan tersebut yaitu komponen M2, yang memiliki nilai amplitude terbesar dibandingkan dengan nilai amplitude komponen lainnya yaitu rata-rata sebesar 0,258 meter. Komponen tersebut memiliki pengaruh yang besar dalam pembentukan pasang surut.

Hasil selanjutnya untuk perhitungan nilai Formzahl memperoleh nilai sebesar 0,47 stasiun Meulaboh; 0,35 untuk stasiun Sibolga dan Padang. Hasil tersebut dikategorikan sebagai tipe Campuran Condong Harian Ganda. Proses pengolahan data Least Square ini juga dilakukan verifikasi data dengan data observasi pasang surut, yaitu dengan menggunakan Root Mean Square Error (RMSE). Nilai RMSE yang diperoleh pada stasiun Meulaboh yaitu sebesar 0,085 m; Sibolga sebesar 0,12 m; dan Padang sebesar $0,079 \mathrm{~m}$.

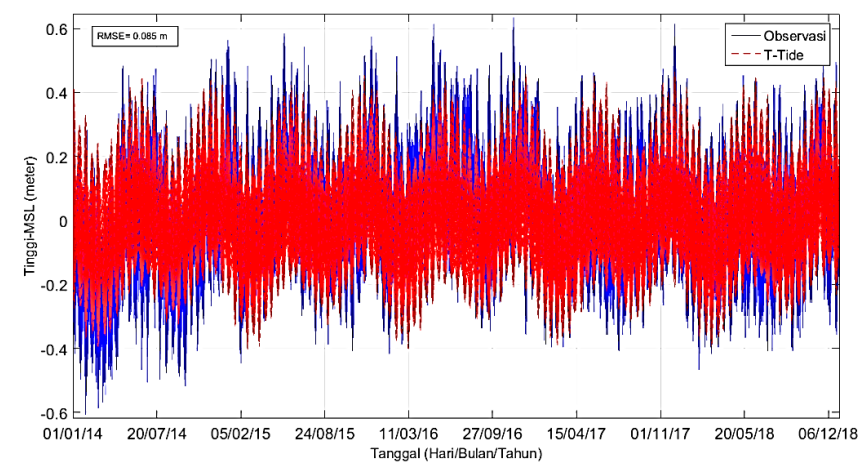

(a) 


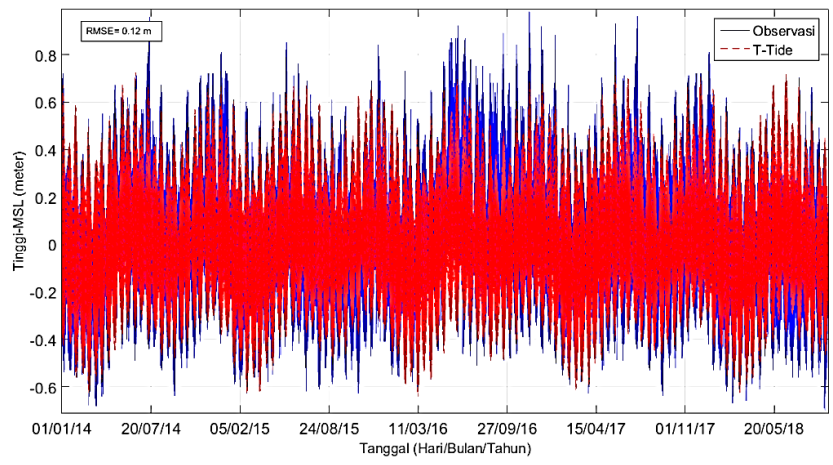

(b)

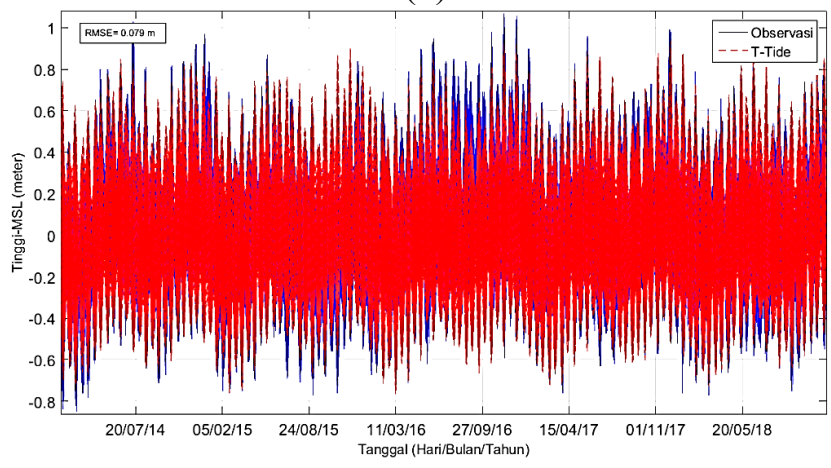

(c)

Gambar 1. (a) Perbandingan stasiun Meulaboh; (b) Perbandingan stasiun Sibolga; dan (c) Perbandingan stasiun Padang

\section{Metode Fourier}

Proses pengolahan metode Fast Fourier Transform merupakan hasil transformasi pasang surut dari domain periode (waktu) menjadi domain frekuensi. Data tersebut dalam lingkup frekuensi diungkapkan sebagai sejumlah gelombang sederhana, yang mempunyai frekuensi dan amplitude tertentu. Berikut gambar sinyal grafik frekuensi yang ditunjukkan pada Gambar 2. Berdasarkan Gambar 2 yaitu grafik plot sinyal frekuensi, ditunjukkan memiliki beberapa puncak. Puncak pada sinyal frekuensi tersebut apabila semakin tinggi puncaknya, maka semakin signifikan frekuensi tersebut terhadap sinyal keseluruhan. Puncak tersebut disebut juga dominan yang berpengaruh dalam kontribusi pasang surut. Identifikasi komponen pasang surut berguna untuk melihat dimana saja yang berpengaruh besar. Hasil masing-masing stasiun memiliki puncak tertinggi yang sama yaitu terdapat pada siklus komponen semidiurnal. Identifikasi komponen tersebut lebih jelasnya dapat dilihat pada Gambar 3.

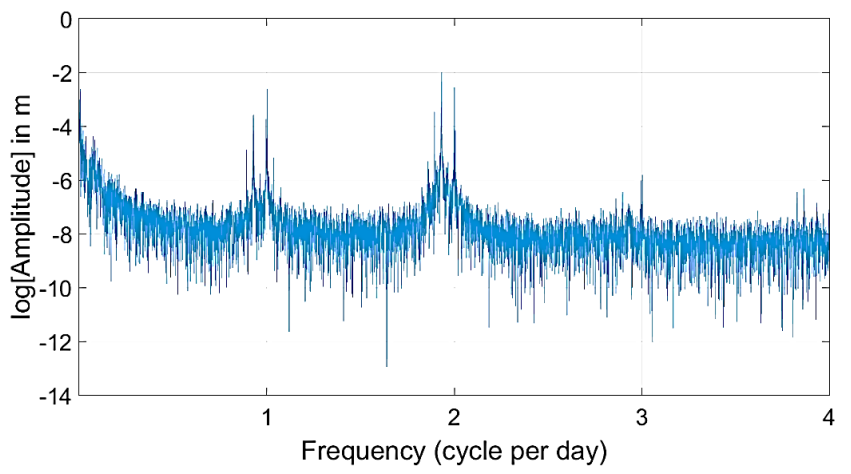

(a) 


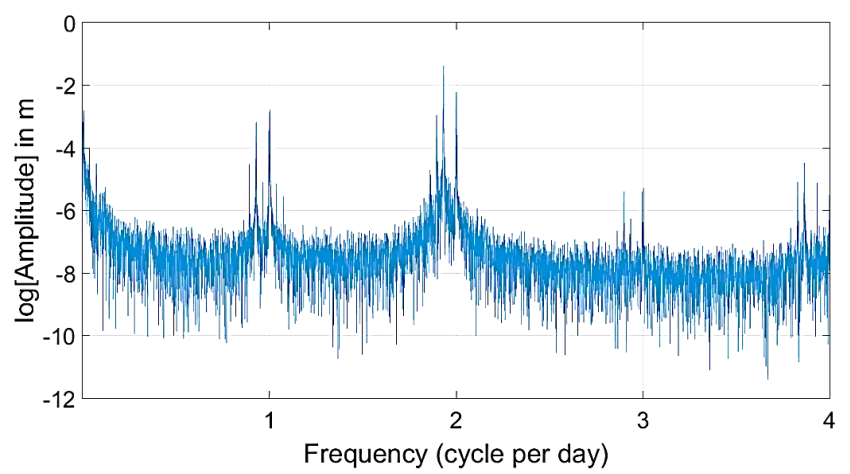

(b)

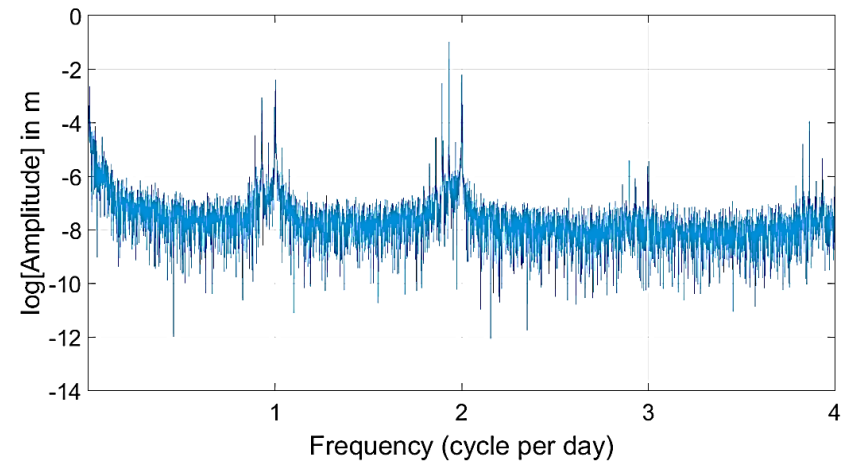

(c)

Gambar 2. (a) Grafik Sinyal Frekuensi Meulaboh; (b) Grafik Sinyal Frekuensi Sibolga; dan (c) Grafik Sinyal Frekuensi Padang

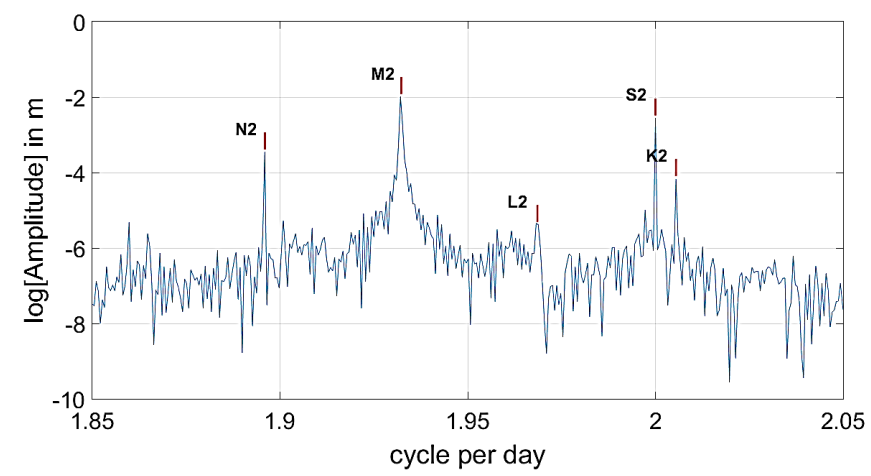

(a)

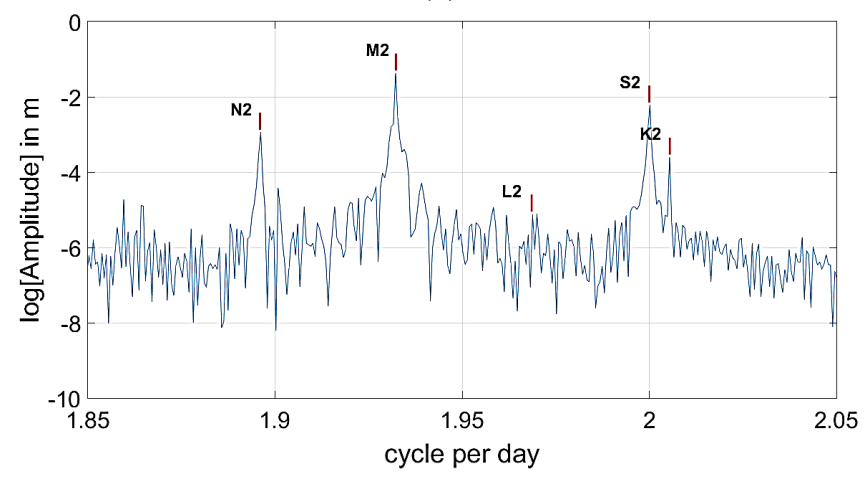

(b) 


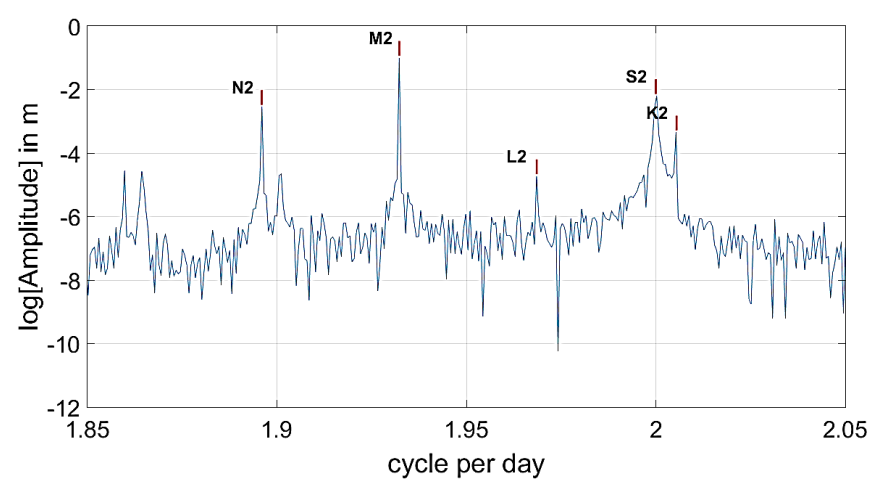

(c)

Gambar 3. (a) Identifikasi Komponen Semi-diurnal Meulaboh; (b) Identifikasi Komponen Semidiurnal Sibolga; dan (c) Identifikasi Komponen Semi-diurnal Padang

Terlihat dari ketiga gambar identifikasi komponen pasang surut pada masing-masing stasiun, grafik tesebut merupakan gambar diperbesar dalam melihat komponen dominan dengan lebih jelas. Teridentifikasi pada siklus komponen semidiurnal tersebut pucak dominan berada pada komponen M2, yang dapat dipastikan bahwa komponen M2 memiliki pengaruh besar terhadap pembentukan pasan surut. Identifikasi ini memperoleh hasil yang sama pada ketiga stasiun. Diketahui juga untuk nilai amplitudenya yaitu stasiun Meulaboh sebesar 0,136 m; Sibolga sebesar 0,253 m; dan Padang sebesar $0,367 \mathrm{~m}$. Nilai tersebut merupakan nilai amplitude terbesar dibandingkan dengan komponen yang lainnya.

Tipe pasang surut juga dapat ditentukan dengan hasil perhitungan nilai Formzahl. Hasil dari metode fourier ini pada stasiun Meulaboh menghasilkan nilai Formzahl sebesar 0,46; Sibolga sebesar 0,27 dan Padang sebesar 0,28. Nilai Formzahl yang diperoleh tersebut menujukkan kategori tipe pasang surut Campuran Condong Harian Ganda.

\section{Perbandingan Metode Least Square dan Fourier}

Hasil yang diperoleh dari metode Least Square dan Fourier memberikan perbedaan dan persamaan antara kedua metode. Perbedaan yang diperoleh yaitu berada pada komponen harmonik yang diperoleh pada masing-masing lokasi. Least Square mengidentifikasi sebanyak 68 komponen harmonik pasang surut. Metode Fourier hanya mengidentifikasi komponen harmonik sebanyak 16 komponen. Pengolahan dengan kedua metode juga memberikan persamaan yang terdapat pada karakteristik pasang surut dan komponen dominan yang diperoleh di masing-masing lokasi. Kedua metode memberikan tipe pasang surut yang sama yaitu tipe pasang surut campuran condong harian ganda dan didominasi oleh komponen M2. Hasil tersebut namun memberikan nilai Formzahl dan nilai amplitude komponen M2 yang bervariasi, seperti yang disajikan pada Gambar 4 dan 5.

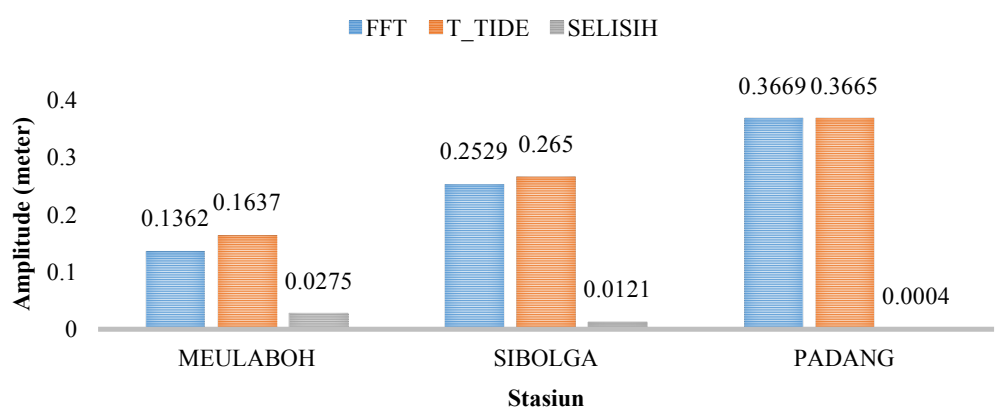

Gambar 4. Perbandingan Nilai Amplitude Komponen M2 


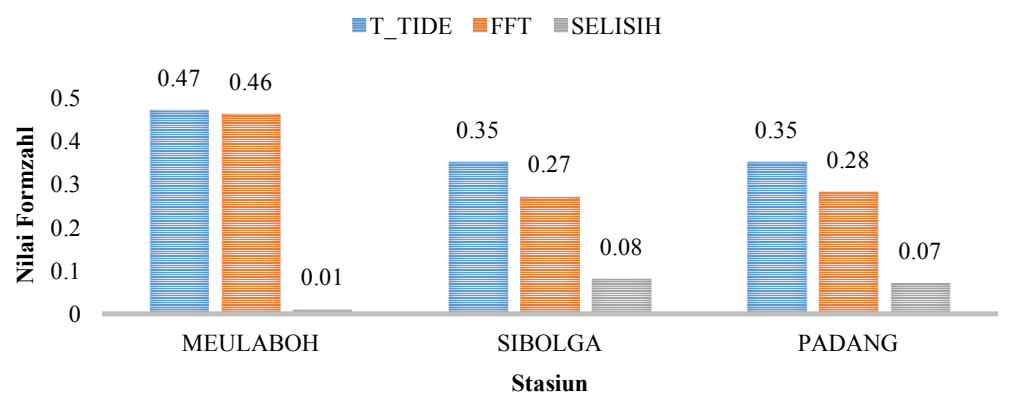

Gambar 5. Perbandingan Nilai Formzahl di 3 lokasi Perairan Barat Sumatera

\section{PEMBAHASAN \\ Komponen Pasang Surut}

Jumlah komponen yang diperoleh dari kedua metode memberikan hasil yang berbeda. Metode Least Square memperoleh hasil yang lebih banyak yaitu sebanyak 68 komponen harmonik pasang surut. Komponen yang diperoleh memberikan jumlah sebanyak demikian diduga karena data pengamatan yang digunakan cukup panjang dan lama, yaitu selama 5 tahun. Pernyataan tersebut diperkuat oleh Supriyono et al. (2015), bahwa semakin lama pengamatan maka komponen yang diperoleh akan semakin banyak sehingga dalam memprediksi pasang surut diharapkan memberikan hasil yang lebih baik. Identifikasi komponen yang dihasilkan pada metode Fourier menggunakan input berupa periode komponen yang dihasilkan dari Least Square. Pada metode tersebut hanya mengidentifikasi komponen harmonik sebanyak 16 komponen, namun identifikasi komponen tersebut dapat ditentukan dengan menambahkan atau mengurangi komponen sesuai dengan yang dibutuhkan.

Hasil dari kedua metode tersebut diperoleh juga komponen dominan yang sama yaitu komponen M2. Komponen dominan yang dihasilkan namun memiliki nilai amplitude berbeda yang terlihat pada Gambar 4. Nilai amplitude komponen M2 menunjukkan selisih hanya berkisar 0,0004-0,0275 meter. Hasil tersebut menujukkan diantara kedua metode menghasilkan prediksi yang baik. Penyataan tersebut diperkuat oleh Yamin (2015), bahwa apabila data semakin panjang, maka kualitas data observasi akan mendapatkan hasil yang semakin baik. Berkaitan dengan nilai periode yang akan semakin tepat begitu juga pada nilai amplitudenya, sehingga panjang data observasi akan sangat berpengaruh untuk mendapatkan nilai konstanta pasang surut mendekati keadaan yang sebenarnya.

\section{Nilai Formzahl}

Karakteristik tipe pasang surut dari kedua metode memberikan hasil yang sama yaitu Campuran Condong Harian Ganda. Tipe pasang surut dari kedua metode tersebut namun memiliki nilai Formzahl yang berbeda. Seperti yang disajikan pada Gambar 5, bahwa nilai formzahl yang dihasilkan hanya memiliki selisih 0,01 - 0,08. Perbedaan nilai Formzahl tersebut diduga karena hasil nilai amplitude yang diperoleh setiap komponennya memberikan nilai yang berbeda. Pernyataan tersebut diperkuat oleh Poerbandono dan Djunarsjah (2005), bahwa berbedanya range pasut disebabkan karena adanya perbedaan pada parameter yang dihasilkan. Perbedaan tersebut berada pada nilai konstanta pasang surut dan konstituen pasang surut yang dimiliki pada masing-masing model.

\section{Karakteristik Pasang Surut di Perairan Barat Sumatera}

Perairan Barat Sumatera memiliki kondisi pasang surut yang bervariasi di masing-masing stasiun lokasi. Terlihat pada datum pasang surutnya yang terlihat pada Tabel 1. Meulaboh memiliki elevasi pasang surut yang paling rendah, sedangkan untuk elevasi pasang surut yang paling tinggi berada di stasiun Padang. Kondisi geografis dan faktor lokal maupun astronomis pada masing-masing lokasi sangat berpengaruh pada hasil tersebut. Pengaruh faktor lokal maupun astronomis menurut pendapat Nontji (1993), faktor tersebut dapat mempengaruhi variasi nilai datum pasang surut. Seperti tekanan 
atmosfir, densitas air laut, penguapan, arus laut, curah hujan ataupun adanya human error dalam pengambilan data pasang surut.

Hasil keseluruhan komponen yang diperoleh dari metode Least Square maupun Fourier dapat mengidentifikasi komponen yang mendominasi di Perairan Barat Sumatera yaitu komponen M2 dengan nilai amplitude komponen rata-rata sebesar 0,258 meter. Komponen tersebut memiliki pengaruh yang besar dalam pembentukan pasang surut. Sesuai dengan yang dinyatakan Pinet (1992) dalam Rampengan (2013), bahwa konstanta pasang surut M2 memperlihatkan kekuatan pasang surut yang dibangkitkan oleh bulan. Nilai konstanta M2 terbesar karena faktor bulan lebih dominan dibandingkan dengan faktor pengaruh matahari.

Tipe pasang surut yang diperoleh pada Perairan Barat Sumatera dengan menggunakan Least Square maupun Fourier memberikan tipe pasang surut yang sama. Nilai Formzahl untuk Perairan Barat Sumatera diperoleh rata-rata sebesar 0,36 dengan tipe pasang surut yaitu Campuran Condong Harian Ganda. Sesuai dengan Wyrtki (1961), dihasilkan pasang surut perairan Barat Sumatera termasuk dalam kategori tipe pasang surut Campuran Condong Harian Ganda. Hasil pada penelitian ini juga sesuai dengan penelitian Sidabutar et al. (2016) yang melakukan analisis pasang surut di Perairan Barat Sumatra dan mendapatkan kriteria tipe pasang surut yang sama. Kriteria tipe yang diperoleh tersebut sesuai dengan Samudra Hindia, sehingga menandakan bahwa hasil komponen pasang surut dari penelitian ini sesuai dengan kondisi pasang surut lokasi penelitian.

\section{KESIMPULAN}

Berdasarkan penelitian yang telah dilakukan dapat disimpulkan bahwa Analisis pemodelan yang dilakukan dengan metode Least Square dan Fourier di Perairan Barat Sumatera memberikan perbedaan dan persamaan pada beberapa parameter. Perbedaan yang diperoleh berada pada jumlah komponen yang dihasilkan, metode Least Square mengidentifikasi komponen yang lebih banyak yaitu sebanyak 68 komponen. Diperoleh juga persamaan pada karakteristik pasang surutnya, yaitu kedua metode memberikan tipe pasang surut Campuran Condong Harian Ganda dengan nilai Formzahl ratarata sebesar 0,36 , dan pembentukan pasang surut didominasi komponen M2 dengan nilai amplitude ratarata sebesar 0,258 meter.

\section{DAFTAR PUSTAKA}

Pariwono, J.I. 1989. Gaya Penggerak Pasang Surut.Pusat Penelitian dan Pengembangan Oseanologi (P3O) LIPI, Jakarta.Pinet, P.R., 1992. Oceanography, An Introduction to The Planet Oceanus. West Publishing Comp. United States of America.

Rampengan, R.M. 2013. Amplitudo konstanta Pasang Surut M2, S2, K1 dan O1 di Perairan Sekitar Kota Bitung Sulawesi Utara. Jurnal Ilmiah Platax., 9(1): 27-30.

Richasari, D D., Rochmawati, C N., dan Fitriana, D. 2019. Analisis Perbandingan Konstanta Pasang Surut Air Laut Menggunakan Software GeoTide dan Toga (Studi Kasus : Stasiun Pasang Surut Surabaya, Jawa Timur, Indonesia). Dalam : Seminar Nasional SPI-4 di Padang tanggal 10 Oktober 2019.

Sidabutar, Y L., Sasmito, B., dan Amarrohman, F J. 2016. Analisis Sea Level Rise Dan Komponen Pasang Surut Dengan Menggunakan Data Satelit Altimetri Jason-2. Jurnal Geodesi Undip., 5 (1) : $243-252$

Sugiyono. 2011. Metode Penelitian Kuantitatif, Kualitatif dan R\&D. Alfabeta, Bandung.

Supriyono et al. 2015. Analisa dan Perhitungan Prediksi Pasang Surut Menggunakan Metode Admiralty dan Metode Least Square (Studi Kasus Perairan Tarakan Dan Balikpapan). Jurnal Chart Datum., $1(1): 1-68$

Syahputra H., dan Nugraha BA. 2016. Analisis Perbandingan Akurasi Model Prediksi Pasang Surut : Studi Kasus di Selat Larantuka, Flores Timur, Nusa Tenggara Timur. Maspari Journal., 8 (2) : 119-126

Wyrtki, K. 1961. Physical Oceanography of the Southeast Asian Waters. Naga Report 2. La Jolla. 